\title{
Rolf Niedergerke (1921-2011): a life in muscle research
}

\author{
David J. Miller
}

Received: 10 September 2012/ Accepted: 12 September 2012

(C) Springer Science+Business Media Dordrecht 2012

\begin{abstract}
This obituary provides some detail and background to the life and work of a pioneer of muscle physiology, Rolf Niedergerke, who died in December 2011 aged 90. His name is perhaps most widely known for his role in the discovery of the sliding filament mechanism of muscle contraction in collaboration with Andrew Huxley (which complemented the independent studies of HE Huxley and Jean Hanson). His other major contributions were to the 'calcium story' of muscle activation, particularly for the heart. In a long career, his intellectual and experimental excellence contributed some keystones of our present understanding of the role of cellular $\mathrm{Ca}^{2+}$ in muscle contraction and cardiac excitation-contraction coupling and of the $\mathrm{Ca}-\mathrm{Na}$ exchange process.
\end{abstract}

Keywords Obituary - Calcium-sodium antagonism . Excitation-contraction coupling · Cardiac muscle - Sliding filament mechanism - Calcium fluxes - Heart muscle . Calcium-sodium exchange $\cdot$ Cardiac action potential

Rolf Niedergerke, a pioneer of muscle physiology, died on 27 December 2011 aged 90 . He is perhaps most widely known for his role in the discovery of the sliding filament mechanism of muscle contraction. His other major contributions were to the 'calcium story' of muscle activation, particularly for cardiac muscle. He retained a reserved personality throughout his long scientific life, notably eschewing many opportunities he had to present his work at conferences or through review articles. His scrupulous

D. J. Miller $(\bowtie)$

School of Life Sciences, University of Glasgow,

Glasgow, United Kingdom

e-mail: David.Miller@glasgow.ac.uk

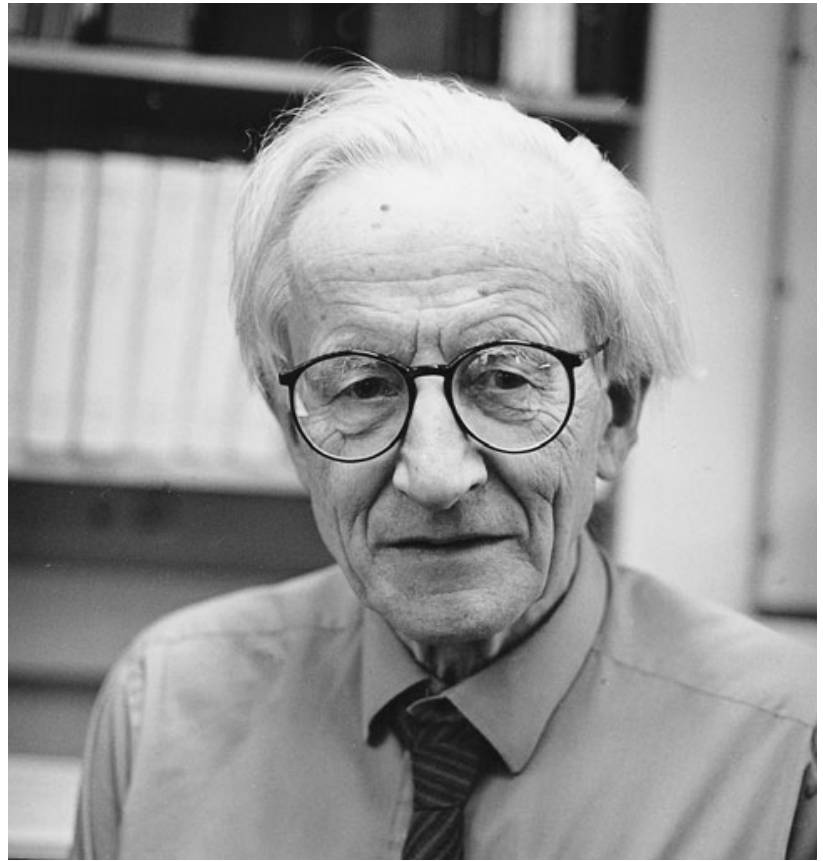

Rolf Niedergerke (Photo by Martin Rosenberg (C) The Physiological Society)

attendance to the limitations of experimental work resulted in publications that were full of detail and insightful caveats but were often challenging for his readers. He was reluctant to speculate beyond what he felt the data permitted. Despite a long and active career, he published fewer than 50 papers. To present-day workers this will seem a modest total. However, ten of his works have each been cited more than 100 times (at an average of 275 by March 2012). The case can be made that his work was more influential than even this impressive citation rate attests. 
Rolf was born on 30 April 1921 at Mülheim an der Ruhr, Germany. He studied medicine throughout the Second World War, mainly at Freiburg University before receiving his MD at the Charles University, Prague in 1945. As a future medical officer, he had been exempted from military service. In 1945, he was briefly imprisoned by invading Russian troops before escaping to continue clinical practice in his home city. He started his scientific work in 1947 at the Physiological Institute, Göttingen under Hermann Rein, studying the electrical activity of nerve fibres. First, he had to build an electrophysiological rig, despite the shortage of electronic equipment in postwar Germany. This provided him with invaluable experience of practical electronics. (It has been remarked that the electronics workshop in Göttingen was excellent but, at that time, rather preoccupied with building radios for the black market). He studied diphasic action potentials and conduction velocity in sciatic frog nerves. The friendship between Hermann Rein and Alexander von Muralt in Bern, Switzerland, led Rolf to work in the Theodor Kocher Institute there. Robert Stämpfli taught him how to dissect single myelinated fibres. Rolf worked partly with Stämpfli and Eduard Coraboeuf on the effects of $\mathrm{CO}_{2}, \mathrm{pH}$ and $\mathrm{Ca}^{2+}$ on the threshold potential and rheobase of isolated nodes of Ranvier.

Around 1951, Andrew Huxley changed his research interest from nerve to muscle and constructed an interference microscope specifically to reinvestigate the striation pattern of living skeletal fibres. Stämpfli recommended Rolf to him as an ideal collaborator for the technical challenges ahead. Moreover, Rolf was already familiar with the work of the early German microscopists on skeletal muscle striation patterns. By 1954, Huxley and Niedergerke could show that the anisotropic ('A') bands, that contain the myosin filaments, do not change length during active shortening, or during passive stretch. They concluded that this observation "... makes very attractive the hypothesis that during contraction the actin filaments are drawn into the A-bands, between the rodlets of myosin. ... If a relative force between actin and myosin is generated at each of a series of points in the region of overlap in such sarcomeres, then tension per filament should be proportional to the number in this zone of overlap". This is an unequivocal statement of the sliding filament mechanism, the modern paradigm of muscle contraction. All these predictions for the mechanism were subsequently confirmed. Hugh Huxley and Jean Hanson, using quite different methods involving isolated myofibrils, X-ray diffraction, phase-contrast-and electron microscopy, had arrived at the same conclusion independently. The two groups published their result in consecutive notes in the same issue of Nature (22nd May 1954). The 'birth of the sliding filament concept' (Maruyama 1995) was a revolution in muscle research and ultimately for the study of cellular motility overall. Nature celebrated the 50th anniversary of these papers (in 2004). Huxley and Niedergerke's detailed work was not fully reported until 1958.

On the heels of this seminal work, Rolf briefly reported the application of $\mathrm{Ca}^{2+}$ via an intracellular micropipette in single skeletal fibres observed under the interference microscope (Niedergerke, 1955). Brief electrophoretic injection of $\mathrm{Ca}^{2+}$ provoked localised shortening in the immediate vicinity of the electrode tip. He suggested that $\mathrm{Ca}^{2+}$ ions activate a link to contraction, perhaps acting specifically since neither $\mathrm{K}^{+}$nor $\mathrm{Mg}^{2+}$ proved effective. These findings cemented prior work by Heilbrunn and Wiercinski (1947) who had used a cruder, pressure injection technique in cut, unrestrained fibre segments. Rolf's pilot study was not followed up or reported in detailpartly because of limited experimental time on the critical interference microscope. However, this work indicated his new field of interest: the activation of contraction in muscle and the role of $\mathrm{Ca}^{2+}$. He worked almost exclusively on this topic to the end of his scientific career.

Rolf moved from Cambridge to London in 1955, joining the Biophysics Department at University College. A suggestion by Bernard Katz shifted Rolf's interest from skeletal to cardiac muscle (see Niedergerke and Page, 1992). In this he was following a celebrated previous inhabitant of the same labs, Sydney Ringer (1835-1910), whose meticulous approach to science and reserved personality had much in common with Rolf. The peculiar sensitivity of cardiac muscle to any manipulation of bathing ionic conditions perhaps seemed to offer a tractable route to understanding 'excitation-contraction coupling' (Alexander Sandow's term, coined in 1952) and the role of calcium.

Rolf initially used fine strips dissected from frog ventricle. He measured monophasic action potentials and isometric force making two important studies $(1956 \mathrm{a}, \mathrm{b})$ of the relationship between membrane potential $\left(\mathrm{E}_{\mathrm{m}}\right)$, beatrate, $\mathrm{Ca}^{2+}$ and contraction, including the use of high- $\mathrm{K}^{+}$ induced depolarisation to control $\mathrm{E}_{\mathrm{m}}$.

Late in 1956, Hans-Christoph Lüttgau joined Rolf-also via the Physiological Institute in Bern - to address the role of $\mathrm{Ca}^{2+}$ in tension activation. They followed up work by Wilbrandt and Koller (1948), confirming that $\mathrm{Ca}^{2+}$ and $\mathrm{Na}^{+}$affect contraction antagonistically. Both twitch and contracture tension proved to be a sigmoidal function of the solution's $\left[\mathrm{Ca}^{2+}\right] /\left[\mathrm{Na}^{+}\right]^{2}$ quotient. They suggested (1957, 1958) that $\mathrm{Ca}^{2+}$ and $\mathrm{Na}^{+}$ions attach to a sarcolemmal binding site that, even in combination with either $\mathrm{Ca}^{2+}$ or $\mathrm{Na}^{+}$, bears net electric charge. When $\mathrm{Ca}^{2+}$-bound, this complex-assumed to move within the membrane during the action potential-might promote contraction. Rolf (working with EJ Harris 1957) also revealed that this mechanism generates transmembrane ion fluxes. By using 
${ }^{45} \mathrm{Ca}$ tracer, they showed net $\mathrm{Ca}^{2+}$ uptake by cells exposed to media of increased $\left[\mathrm{Ca}^{2+}\right] /\left[\mathrm{Na}^{+}\right]^{2}$.

These findings, and the algebraic formalism developed to describe them, form keystones of subsequent work specifically characterising the $\mathrm{Ca}-\mathrm{Na}$ exchange mechanism (CaNaX) started by Harald Reuter (Reuter and Seitz 1968). The algebraic description of receptor-based antagonism in the 1958 paper was further developed in part from an exchange of letters between Alan Hodgkin and Rolf. Hodgkin had broken his anonymity as the referee for the Journal of Physiology paper by suggesting a way of describing the voltage-sensitivity of $\mathrm{Ca}-\mathrm{Na}$ antagonism in explicit terms, but added "I expect you have been considering much of this already" (Hodgkin 1958). (This model of voltage sensitivity was detailed by Lüttgau 1963 in Milan, Lüttgau, 1965). Subsequently, Miller and Moisescu (1976) provided a scheme to account for the ion fluxes and force production implicated in $\mathrm{Ca}-\mathrm{Na}$ antagonism, sensu stricto. Finally, the phenomenon of $\mathrm{Ca}-\mathrm{Na}$ antagonism has been described quantitatively in terms of the present-day model of the CaNaX mechanism by Miller and Smith 2010).

Rolf next analysed the influence of external $\left[\mathrm{Ca}^{2+}\right]$ and $\left[\mathrm{Na}^{+}\right]$, as well as beat rate, on ${ }^{45} \mathrm{Ca}$-tracer fluxes (Niedergerke 1963a, b). Then, with Dick Orkand, he focussed on the influence of $\mathrm{Ca}^{2+}$ on the overshoot of the action potential (1964). They distinguished any 'indirect' role of $\mathrm{Ca}^{2+}$ on other current-carriers (e.g. via surface charge effects) before concluding that $\mathrm{Ca}^{2+}$ itself must be a current-carrying ion that contributes to the action potential (Niedergerke and Orkand 1966a, b). (The role for $\mathrm{Ca}^{2+}$ ions as a current carrier was soon convincingly confirmed in voltage clamp experiments e.g. those by Beeler and Reuter 1970). Rolf's $\mathrm{Ca}^{2+}$-flux and electrophysiological studies were followed by work on the dynamics of twitchtension control by heart rate and extracellular $\mathrm{Ca}^{2+}$ (Chapman and Niedergerke 1970a, b).

Rolf then addressed a key concept of putative $\mathrm{Ca}-\mathrm{Na}$ exchange mechanisms, namely whether intracellular $\left[\mathrm{K}^{+}\right]$ and $\left[\mathrm{Na}^{+}\right]$might regulate the strength of the heartbeat (Gadsby et al. 1971). Their results did (and do) not fit easily with proposals concerning $\mathrm{CaNaX}$ that were emerging then, perhaps because few other studies directly address the dynamic control of tension (as observed in $\mathrm{Ca}-$ $\mathrm{Na}$ antagonism) as opposed to ion fluxes and considerations of steady-state intracellular ion concentrations (more directly concerning $\mathrm{CaNaX}$ ).

In his only departure, post 1955, from studying the heart, Rolf's 1977 paper with the two Davids-Gadsby and Ogden-addressed the electrogenic sodium pump in skeletal fibres. By this time, Rolf had already been collaborating for several years with Sally Page (e.g. Page and Niedergerke 1972), with whom most of his subsequent research was done. Various experimental and theoretical strands underpinned an interpretation of their wider-ranging functional studies on the actions of caffeine; adrenaline and ATP on the heart (see Niedergerke and Page 1981a, b).

Some sight of Rolf the man must not be lost in this description of his scientific life; Sally Page has reminded me that Rolf's dry humour was a constant feature of his personality, often displayed in lab teaching and in private life. In his youth Rolf had played both flute and violin in chamber music groups: music might well have become his profession had the war and his medical studies not intervened. Music was to remain a life-long passion. Sally and Rolf travelled widely together, combining hill- and mountain-walking (Europe, Turkey, North Africa, Madeira) with exploring old towns and museums. In London, weekly museum and gallery visits, theatre and concerts provided Rolf's relaxations together with walking, reading and music. As former colleague Don Jenkinson noted "those privileged to know him well came to appreciate his unobtrusive kindliness and the breadth of both his scholarship and interests (especially in European history and art)."

Rolf received the first Rudolf Buchheim Prize of the German Pharmacological Society and was made an Honorary Member of the Physiological Society in 1987, when he retired, becoming Emeritus Reader in Biophysics at UCL.

Over his career, Rolf Niedergerke was invited to a number of symposia, but he invariably declined. This characteristic reticence to push major findings was regretted, in particular by those keen to promote his career and his work. Otto Hutter has described this aspect of Rolf's personality as the "principle-led disapproval of any form of self-promotion". However, Rolf's intellectual and experimental excellence contributed some keystones of our present understanding of the role of cellular $\mathrm{Ca}^{2+}$ in muscle contraction and cardiac EC coupling and of the $\mathrm{Ca}-\mathrm{Na}$

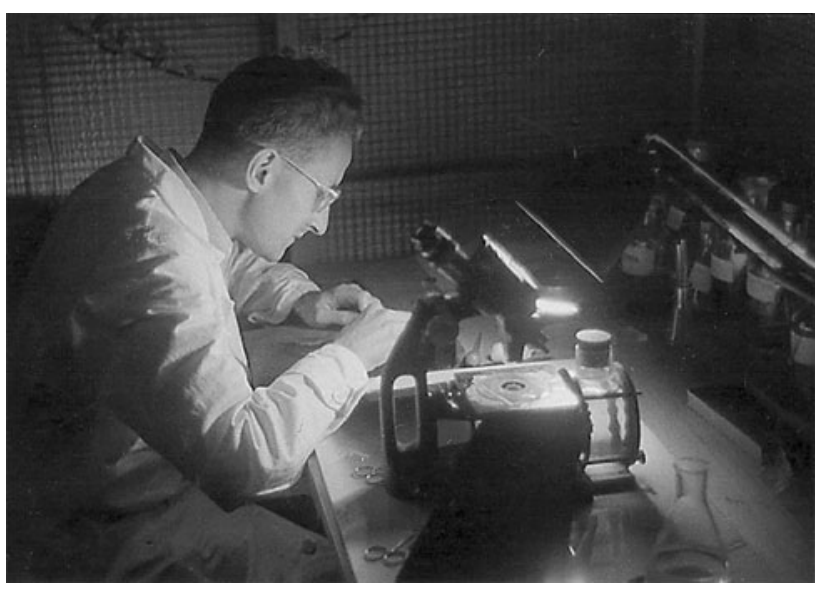

Rolf Niedergerke at the dissection table. (Photo courtesy of Sally Page) 
exchange process, But he also contributed to a crowning achievement of cell physiology through his part in a collaboration that helped to reveal the sliding filament mechanism of muscle contraction.

Acknowledgments I wish to express my gratitude to Hans-Christoph Lüttgau who collaborated with me in an earlier version of this article written for Physiology News and the longer, linked version available via the Physiological Society's website. I am also indebted to Sally Page who provided many key facts about Rolf Niedergerke's life, as well as her personal reflections on his character and life outside science.

\section{References}

Beeler GW, Reuter H (1970) Membrane calcium current in ventricular myocardial fibres. J Physiol 207:191-209

Chapman RA, Niedergerke R (1970a) Effects of calcium on the contraction of the hypodynamic frog heart. J Physiol 211:389-421

Chapman RA, Niedergerke R (1970b) Interaction between heart rate and calcium concentration in the control of contractile strength of the frog heart. J Physiol 211:423-443

Gadsby DC, Niedergerke R, Ogden DC (1977) The dual nature of the membrane potential increase associated with the activity of the sodium/potassium exchange pump in skeletal muscle fibres. Proc Roy Soc (Ser B) 198:463-472

Gadsby DC, Niedergerke R, Page S (1971) Do intracellular concentrations of potassium or sodium regulate the strength of the heart beat? Nature (Lond) 232:651-653

Heilbrunn LV, Wiercinski FJ (1947) The action of various cations on muscle protoplasm. J Cell Comp Physiol 29:15-32

Hodgkin AL (1958) Text quoted from a letter from ALH to R Niedergerke, 24 April 1958: copy provided to me by H-Ch Lüttgau

Huxley AF, Niedergerke R (1954) Structural changes in muscle during contraction. Nature (Lond) 173:971-973

Huxley AF, Niedergerke R (1958) Measurement of the striations of isolated muscle fibres with the interference microscope. J Physiol 144:403-425

Lüttgau H-Ch (1965) The role of calcium ions in excitationcontraction coupling in myocardium. In: Marchetti G (ed) Electrophysiology of the heart (Milan 1963) pp 87-95 Taccardi B. Pergamon Press, London

Lüttgau H-Ch, Niedergerke R (1957) Calcium and the contraction of the heart. Antagonism between calcium and sodium ions. Nature (Lond) 179:1066-1067
Lüttgau H-Ch, Niedergerke R (1958) The antagonism between Ca and $\mathrm{Na}$ ions on the frog's heart. J Physiol 143:486-505

Maruyama K (1995) Birth of the Sliding Filament Concept in Muscle Contraction. JBiochem 117:1-6

Miller DJ, Moisescu DG (1976) The effects of very low external calcium and sodium concentrations on cardiac contractile strength and calcium-sodium antagonism. J Physiol 259:283-308

Miller DJ, Smith GL (2010) Lüttgau \& Niedergerke; the classic study of calcium; sodium antagonism half a century on. J Physiol 588:23-25

Niedergerke R (1955) Local muscle shortening by intracellularly applied calcium. J Physiol 128:12-13P

Niedergerke R (1956a) The 'staircase' phenomenon and the action of calcium on the heart. J Physiol 134:569-583

Niedergerke R (1956b) The potassium chloride contracture of the heart and its modification by calcium. J Physiol 134:584-599

Niedergerke R (1963a) Movements of Ca in fog heart ventricles at rest and during contraction. J Physiol 167:515-550

Niedergerke R (1963b) Movements of Ca in beating ventricles of the frog heart. J Physiol 167:551-580

Niedergerke R, Harris EJ (1957) Accumulation of calcium (or strontium) under conditions of increasing contractility. Nature (Lond) 179:1068-1069

Niedergerke R, Orkand RK (1966a) The dual effect of calcium on the action potential of the frog's heart. J Physiol 184:291-311

Niedergerke R, Orkand RK (1966b) The dependence of the action potential of the frog's heart on the external and intracellular sodium concentration. J Physiol 184:312-334

Niedergerke R, Page S (1981a) Analysis of caffeine's action in single trabeculae of the frog's heart. Proc Roy Soc (Ser B) 213:303324

Niedergerke R, Page S (1981b) Two physiological agents that appear to facilitate calcium discharge from the sarcoplasmic reticulum in frog heart cells: adrenaline and ATP. Proc Roy Soc (Ser B) 213:325-344

Niedergerke R, Page S (1992) Hypodynamic tension changes in the frog heart. In: Simmons RM (ed) Muscular contraction. Cambridge University Press, London, pp 83-106

Orkand RK, Niedergerke R (1964) Heart action potential: dependence on external calcium and sodium ions. Science 146:1176-1177

Page S, Niedergerke R (1972) Structures of physiological interest in the frog heart ventricle. J Cell Sci 11:179-203

Reuter H, Seitz N (1968) The dependence of calcium efflux from cardiac muscle on temperature and external ion composition. J Physiol 195:451-470

Wilbrandt W, Koller H (1948) Die Calciumwirkung am Froschherzen als Function des Ionengleichgewichts zwischen Zellmembran und Umgebung. Helv Physiol Pharm Acta 6:208-221 